THE " Oxford Dictionary" defines scientist simply as "A man of science." It defines man of science (s.v. Science, 6) as : $a$ (a sense ruled out as obsolete); $b$, "In modern use, a man who has expert knowledge of some branch of science (usually, of physical or natural science), and devotes himself to its investigation." All this with no suggestion whatever that the usage is blameworthy or questionable, or that there is any other modern acceptation.

Accordingly, in the "Pocket Oxford Dictionary" published this year, the only definition of scientist given is " (esp.) person learned in one or more of the natural sciences," in which " (esp.) " merely indicates that the limitation to the natural sciences is, though usual, not so far obligatory that, e.g., a pure mathematician might not, exceptionally, be called a scientist.

My opinion is, then, that to refuse the word the now prevalent and extremely convenient sense that you mention, "a worker in the field of physical or biological science," is antiquated pedantry. I may add that nothing is gained by the substitution of man of science, so far as meaning is concerned; for any undesirable vagueness that may attach to scientist comes to it only as a consequence of science's having also more than one sense. But I suspect that those who really have an instinctive (as opposed to a merely imitative) aversion to this use of scientist are influenced not by doubts of its meaning, but by dislike of its (and many other -ist words') slightly abnormal formation; but that is not the point raised in your question. H. W. Fowler.

Moulin de Haut, Guernsey.

So long ago as I840, according to the " Oxford Dictionary," Dr. Whewell, eminent as man of letters as well as man of science, wrote: "We need very much a name to describe a cultivator of science in general. I should incline to call him a Scientist." I do not think the objections to the word on merely literary or linguistic grounds can be maintained. It is a hybrid, but the language is full of hybrids : moreover, it may well be argued that -ist is naturalised as an English termination.

There is, however, another sort of objection which has to be weighed. Like other words in -ist, it has a professional air, as if the man who so described himself were claiming an ex cathedva authority for his utterances. Hence its use is not always complimentary. We see this in its derivatives "scientism" and "scientistic." Similarly, when I have been introduced to a public meeting as an "educationist" or " educationalist," I have wished to be saved from my friends: I would rather be called a schoolmaster. My conclusion is that the term scientist is too convenient to be wholly rejected, but that writers would do well to remember its less complimentary use as a label, and not resort to it too frequently.

I6 Canynge Square, Clifton, Bristol.

$$
\text { J. H. Fowler. }
$$

THE word "scientist" is, in itself, neither better nor worse than dentist, oculist, socialist, or violinist. It would be pedantic, at the present day, to object to it merely on the ground that it begins in one language and ends in another. If it were a new word, introduced for the sake of brevity and convenience by some respectable writer, I should have little objection to it; I should be reluctant to use it myself, but I should not dream of objecting to its use by others.

It seems to me, however, that the word has already got a sort of taint about it, very much as the word "sophist" did in Greek. It is often used in an equi- vocal, or even disparaging, sense, by people who have no great respect either for science or the "scientist." Most men of science would surely rather be called so than be dubbed scientist. The widely used term "Christian Scientist" has helped to make matters worse; what that phrase means I do not know, but if I did know I am sure I should not like it any the better.

On the whole, I take it that the word scientist has been in low company, and I should be very slow to introduce it into better.

\section{St. Andrews.}

D'Arcy W. Thompson.

REGARDING the inquiry contained in your letter, I would say that the word "scientist" has fully established itself in the written and spoken language of scientific workers as well as of non-scientific persons. It is, of course, when one stays to examine it, a hybrid, but like that other hybrid, the mule, it does useful work. After all, there are numbers of hybrid words in our language also doing useful work, and one does not now trouble to look them in the mouth. For example, take the Latin stems with the Greek termination -ist. The psychologists do not blush to use the word "animist" ; they even say "behaviourist." In my opinion, "scientist" is a gentleborn word alongside of " behaviourist," which may well haye besmirched the pages of NATURE.

The University, Manchester.

$$
\text { W. J. Sedgefield. }
$$

I HAVE submitted your inquiry to my son, who is a literary critic. He sees no objection to "scientist," and is rather surprised that it has not been adopted before. He thinks it as well-formed as " artist." $\mathrm{He}$ does not much like words ending in "ist," but concludes that they cannot be avoided.

For myself, I dislike the word, but cannot give a clear reason for the dislike-unless it be that the preposterous term " Christian" prefixed to it has given it an alien significance. On the whole, I feel that the public has forced the word upon us, and that we must succumb.

Normanton House,

Lake, Salisbury.

Personally, I should say " man of science" rather than "scientist" ; but I do not think one can deny to the word scientist its legitimate place in English. It is recorded in the " Oxford Dictionary," together, I admit, with a good many words which a man does not use if he can help it. But the place of "scientist" in the English vocabulary must have been fairly safe since Whewell wrote in I 840 , "We need very much a name to describe a cultivator of science in general. I should incline to call him a Scientist."

\section{University College,} Gower Street, W.C.

In spite of the objections which have been raised to the use of the word "scientist," it may with advantage be used in place of "scientific worker " or " man of science." Whewell seems to have coined the word to describe " a cultivator of science in general." On the whole, there is much to be said in favour of it. It should not, however, in my opinion, be limited to a worker in the field of physical or biological science.

King's College, London.

$$
\text { NO. } 2875 \text {, VOL. I I } 4 \text { ] }
$$

